\title{
DEPUDECIN: A NOVEL COMPOUND INDUCING THE FLAT PHENOTYPE OF NIH3T3 CELLS DOUBLY TRANSFORMED By ras- AND src-ONCOGENE, PRODUCED BY Alternaria brassicicola
}

\author{
Makoto Matsumoto, Shigeru Matsutani*, Kenji Sugita, Hiroshi Yoshida, \\ Fumtaki Hayashi, Yoshiniro Terui, Hiroshi Nakai, Nobuo Uotani, \\ Yoshimi Kawamura, Koichi Matsumoto, Jun'ichi ShoJi \\ and TADASHI YOSHIDA
}

Shionogi Research Laboratories, Shionogi \& Co., Ltd., Fukushima-ku, Osaka 553, Japan

(Received for publication November 22, 1991)

\begin{abstract}
A novel compound depudecin inducing the flat phenotype of ras-and src-transformed NIH3T3 cells at a concentration of $1 \mu \mathrm{g} / \mathrm{ml}$ was isolated from the culture broth of Alternaria brassicicola. Based on its spectroscopic characteristics and X-ray crystallographic analysis of its bis-(1S)-(-)camphanate, the structure of depudecin was determined to be $(2 R, 3 S, 4 S, 5 E, 7 S, 8 S, 9 R)$-2,9-dihydroxy3,4;7,8-diepoxy-undeca-5,10-diene.
\end{abstract}

In the course of our screening work from microbial cultures for antitumor agents with detransforming activity ${ }^{1)}$, we found a novel compound in the culture broth of a fungus. This compound which we have designated depudecin induced the flat phenotype of NIH3T3 cells doubly transformed by ras- and $s r c$-oncogene. The fungus was isolated from a soil sample collected in Okinawa, Japan and has been identified as Alternaria brassicicola RF-328.

In this paper, we report the taxonomy and fermentation of the producing organism, and the isolation, structural determination and biological properties of this novel compound.

\section{Materials and Methods}

Taxonomic Studies

The strain RF-328 was isolated from a soil sample collected at Okinawa Prefecture, Japan.

Morphological observations were made with a light microscope with cultures grown at $25^{\circ} \mathrm{C}$ for 21 days on corn meal agar medium. Cultural properties were also observed on corn meal agar medium. Incubation was carried out at $25^{\circ} \mathrm{C}$ for 21 days.

Color assignments were made using the Guide to Color Standard (published by Nihon Shikisai Kenkyusho).

Structural Studies

The UV spectra were measured on a Hitachi 323 spectrometer, IR spectra on a Jasco DS-403G spectrometer, $[\alpha]_{\mathrm{D}}$ on a Perkin-Elmer 241 polarimeter, mass spectra on a Hitachi M-90 mass spectrometer, and NMR spectra on a Varian XL-400 spectrometer in $\mathrm{CDCl}_{3}$ solution with TMS as an internal standard. MP was measured with a Yanagimoto microscope hot-stage apparatus and are uncorrected. TLC was perfomred on pre-coated Silica gel $60 \mathrm{~F}_{254}$ plates (E. Merck). Column chromatography was carried out on Merck Silica gel 60 (230 400 mesh).

Fig. 1. Structure of depudecin (1a).

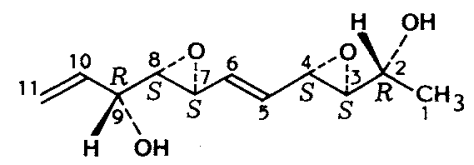


Preparation of Bis-(1S)-(-)-camphanate (1b) of Depudecin

To a dissolved solution of depudecin $(55 \mathrm{mg})$ in dry pyridine $(2.0 \mathrm{ml})$ was added $(1 S)-(-)$-camphanic chloride $(133 \mathrm{mg}$ ) with stirring. The resulting mixture was stirred at room temperature for 60 minutes. The reaction mixture was partitioned between EtOAc and water. The organic layer was washed with $1 \mathrm{~N} \mathrm{HCl}$, $5 \% \mathrm{NaHCO}_{3}$ and brine successively, dried over $\mathrm{Na}_{2} \mathrm{SO}_{4}$, and evaporated in vacuo to leave a residue $(150 \mathrm{mg})$ which was purified by a $\mathrm{SiO}_{2}$ columm chromatography $\left(\mathrm{SiO}_{2} 30 \mathrm{~g}\right.$, eluted with $n$-hexane - EtOAc $(60: 40))$ to afford the bis-( $1 S)-(-)$-camphanate $(38.5 \mathrm{mg}) ; \mathrm{mp} 157 \sim 158^{\circ} \mathrm{C}$ (prism from $\mathrm{EtOH}-\mathrm{EtOAc}$ $(20: 1))$.

\section{X-Ray Diffraction Analysis}

A colorless prism crystal of depudecin bis-(1S)-(-)-camphanate (1b) obtained from EtOH - EtOAc (20:1) having dimensions $0.5 \times 0.4 \times 0.1 \mathrm{~mm}$ was mounted on a Rigaku AFC-5R diffractometer. Intensities were measured using graphite-monochromatized $\mathrm{Cu}-\mathrm{K}_{\alpha}$ radiation by $\omega$ scans in the range $\theta \leq 65^{\circ}$ with a scan width $(2+0.2 \tan \theta)^{\circ}$ and a constant scan speed of $5^{\circ}$ minute ${ }^{-1} .2,586$ unique reflections were measured and corrected for Lorentz and polarization factors, but not for absorption effects.

\section{Biological Assay}

a) Detransformation: The ability of depudecin to flatten the ras- and src-oncogene transformed NIH3T3 cells (ras/src NIH3T3) was examined as follows. Five thousand cells of ras/src NIH3T3 were inoculated into each well of a 96-well plate containing $100 \mu \mathrm{l}$ of DULBECCO's modiffed minimum essential medium (D-MEM) supplemented with 10\% fetal bovine serum (FBS, Flow Laboratories). After overnight incubation at $37^{\circ} \mathrm{C}$, the cells were given $100 \mu \mathrm{l}$ D-MEM (10\% FBS) containing various concentrations of depudecin. With further incubation at $37^{\circ} \mathrm{C}$, the morphological change of the cells was observed under a microscope, and the minimum concentrations of depudecin needed for the flattening were determined.

b) Growth Inhibition: The inhibitory activity of depudecin against the growth of ras/src NIH3T3 was measured by colorimetric MTT assay ${ }^{2)}$ as described previously ${ }^{17}$. Five thousand cells of ras/src NIH3T3 were put into each well of a 96-well plate in $100 \mu \mathrm{l}$ of D-MEM (10\% FBS), and incubated overnight at $37^{\circ} \mathrm{C}$ in a $5 \% \mathrm{CO}_{2}$ incubator. After addition of the drug, the cells were incubated for 48 hours at $37^{\circ} \mathrm{C}$, then MTT(3-(4,5-dimethylthiazol-2-yl)-2,5-diphenyl tetrazolium bromide), $150 \mu \mathrm{g}$ was added to the cell culture, and the plate was incubated further at $37^{\circ} \mathrm{C}$ for 4 hours. After an acid-SDS solution (100 $\mu 1$ of $0.01 \mathrm{~N} \mathrm{HCl}$ in $10 \%$ SDS solution) was added to all wells and mixed throughly to effect solution, the plate was read on an autoreader (Dynatech) using a wave length of $570 \mathrm{~nm}$.

\section{Results and Discussion}

\section{Taxonomy}

Taxonomic properties of the depudecin-producing strain RF-328 are summarized as follows. Colonies are effuse, drak oilvaceous brown to dark blackish brown and velvety. Hyphae branched, septate, hyaline at first and later borwn or olivaceous brown, smooth, $2.0 \sim 7.5 \mu \mathrm{m}$ in width. Conidiophores are usually simple, smooth, erect or ascending, straight or curved, septate, and pale to mid olivaceous brown, up to $70 \mu \mathrm{m}$ in length and $4 \sim 6 \mu \mathrm{m}$ in width. Conidia are mostly in chains up to 10 or more, sometimes branched, acroplerogenous, arising through small pores in the conidiophore wall. They are straight, nearly cylindrical, usually tapering slightly towards the apex, the basal cell rounded, the apical cell resembling a truncated cone, with $1 \sim 8$ transverse septa and $0 \sim 5$ longitudinal septa, often slightly constricted at the septa. They are pale to dark olivaceous brown, smooth or becoming slightly warted with age, $18 \sim 90 \mu \mathrm{m}$ long, $8 \sim 25 \mu \mathrm{m}$ thick in the broadest part.

Based on the taxonomic properties described above, the strain RF-328 was identified as Alternaria brassicicola (Schw.) WILTSHIRE (1947) ${ }^{3}$. The strain RF-328 has been deposited in the Fermentation Research Institute, Agency of Industrial Science and Technology, Japan, under the accession No. FERM P-11387. 
Fermentation

A slant culture of strain RF-328 was inoculated into a 3-liter Erlenmeyer flask containing $800 \mathrm{ml}$ of a medium consisting of glucose $0.5 \%$, Polypepton $0.5 \%$, beef extract $0.5 \%$, yeast extract $0.25 \%$ and $\mathrm{NaCl}$ $0.25 \%\left(\mathrm{pH} \mathrm{7.0)}\right.$. The flask was shaken at $28^{\circ} \mathrm{C}$ for two days on a rotatory shaker at $180 \mathrm{rpm}$. Eight hundred $\mathrm{ml}$ of the culture was transferred to a 30-liter jar fermenter containing 20 liters of the production medium. The production medium contained potato decoction prepared from potato $200 \mathrm{~g}$ and sucrose $20 \mathrm{~g}$ in one liter tap water (pH 7.0). Fermentation was carried out at $28^{\circ} \mathrm{C}$ for 7 days under aeration of 12 liters per minute and agitation at $350 \mathrm{rpm}$.

\section{Isolation and Purification}

The fermentation broth (120 liters) was centrifuged, and the supernatant (110 liters) was applied to a column of Diaion CHP-20P (14 i.d. $\times 47 \mathrm{~cm}$, Mitsubishi Chemical Industries). After washing with water (20 liters), the column was eluted with $30 \%$ aq $\mathrm{MeOH}$. The active fractions (14 liters) were concentrated in vacuo to 7 liters, and then subjected to chromatography on a Diaion CHP-20P column (1.7 liters, 7.5 i.d. $\times 39 \mathrm{~cm}$ ) eluting with $40 \%$ aq $\mathrm{MeOH}$. The active eluate (11 liters) was combined and evaporated in vacuo to give an oily residue $(41.4 \mathrm{~g})$. The $\mathrm{CH}_{2} \mathrm{Cl}_{2}$-soluble fraction $(6.69 \mathrm{~g})$ of this residue was charged on a silica gel column $(150 \mathrm{~g}, 3.1$ i.d. $\times 40 \mathrm{~cm})$ which was eluted in a linear gradient manner from $\mathrm{CH}_{2} \mathrm{Cl}_{2}$ to $4 \% \mathrm{MeOH}-\mathrm{CH}_{2} \mathrm{Cl}_{2}$ (v/v) affording $4.0 \mathrm{~g}$ of depudecin as a colorless oil.

\section{The Physico-chemical Properties and Structural Determination}

The physico-chemical properties of depudecin are summarized in Table 1.

Depudecin gave positive reactions for Dragendorff, iodine vapor and sulfuric acid-charring, but did not for ninhydrin and ferric chloride. The molecular formula was determined as $\mathrm{C}_{11} \mathrm{H}_{16} \mathrm{O}_{4}$ based on high-resolution mass spectral data (HRLSI-MS, $\mathrm{MH}^{+}$obsd $m / z 213.1126 ; \mathrm{C}_{11} \mathrm{H}_{17} \mathrm{O}_{4}$ requires 213.1126). The IR spectrum showed the presence of a hydroxy group $\left(3600 \mathrm{~cm}^{-1}\right)$, and the UV spectrum had no absorption maxima. The ${ }^{1} \mathrm{H}$ and ${ }^{13} \mathrm{C}$ NMR spectrum exhibited the presence of one methyl, four $-\mathrm{CH}-\mathrm{O}$, two $-\mathrm{CHOH}$, one $-\mathrm{CH}=\mathrm{CH}-$, and one $-\mathrm{CH}=\mathrm{CH}_{2}$ groups.

Homonuclear Hartmann-Hahn (HOHAHA) spectrum and heteronuclear multiple bond correlation (HMBC) spectrum superimposed on heteronuclear multiquantum coherence (HMQC) were shown in Figs. 2 and 3. Connectivities from $1-\mathrm{H}$ through $11-\mathrm{H}$ were established by the analysis of ${ }^{1} \mathrm{H}-{ }^{1} \mathrm{H}$ COSY and HOHAHA spectrum to reveal the planar structure of depudecin. The connectivity from C-4 through C-7 was suggested since an oxymethine proton at $\delta 3.37(4-\mathrm{H})$ showed a correlation peak with an oxymethine proton at $\delta 3.42(7-\mathrm{H})$ via $5-\mathrm{H}$ and $6-\mathrm{H}$ (Fig. 2) in spite of the chemical shift degeneration of $\mathrm{H}-5$ and $\mathrm{H}-6$. This was confirmed by the fact that $\mathrm{C}-5(\delta$ $132.55)$ has cross peaks with protons at $3-\mathrm{H}(\delta 2.90)$, 4-H $(\delta 3.37)$, and $6-\mathrm{H}(\delta 5.70)$ and $7-\mathrm{H}(\delta 3.42)$ and C-6 $(\delta 132.06)$ with those at $4-\mathrm{H}(\delta 3.37), 5-\mathrm{H}(\delta$ $5.69), 7-\mathrm{H}(\delta 3.42)$ and $8-\mathrm{H}(\delta$ 3.00) in HMBC spectrum (Fig. 3 and Table 2). The presence of epoxide rings were inferred from the large ${ }^{1} \mathrm{H}-{ }^{13} \mathrm{C}$ coupling constant $(174 \sim 176 \mathrm{~Hz})$ of $\mathrm{C}-3, \mathrm{C}-4, \mathrm{C}-7$ and C-8 signals. Configuration of both epoxides was determined to be trans on the basis of the coupling
Table 1. Physico-chemical properties of depudecin.

\begin{tabular}{|c|c|}
\hline Appearance & Colorless oil \\
\hline Molecular formula & $\mathrm{C}_{11} \mathrm{H}_{16} \mathrm{O}_{4}$ \\
\hline $\begin{array}{l}\mathrm{MW}(\mathrm{M}+\mathrm{H})^{+} \\
\quad(\mathrm{HRLSI}-\mathrm{MS})\end{array}$ & $\mathrm{m} / \mathrm{z} 213.1126(\Delta 0.0 \mathrm{mmu})$ \\
\hline$[\alpha]_{D}^{24}$ & $-35.8^{\circ}\left(c 0.52, \mathrm{CH}_{3} \mathrm{OH}\right)$ \\
\hline $\mathrm{UV}\left(\mathrm{CH}_{3} \mathrm{OH}\right)$ & End absorption \\
\hline IR $\left(\mathrm{CHCl}_{3}\right)$ & $\begin{array}{l}3600,1604,1142,965 \\
892 \mathrm{~cm}^{-1}\end{array}$ \\
\hline TLC (Rf value) & $0.26^{\mathrm{a}}, 0.48^{\mathrm{b}}$ \\
\hline
\end{tabular}


Fig. 2. HOHAHA spectrum of depudecin.

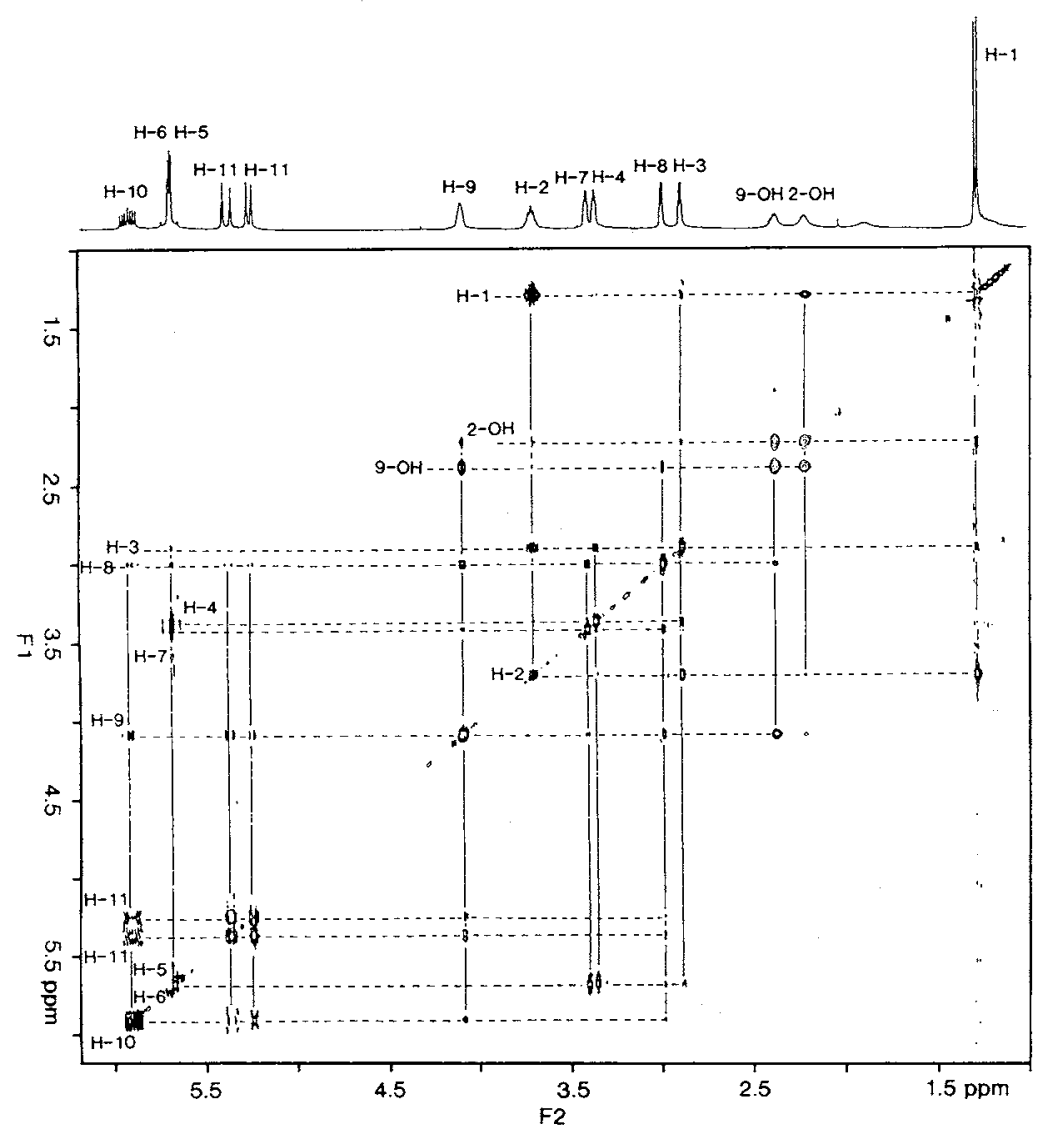

Fig. 3. HMBC spectrum superimposed of HMQC spectrum for depudecin.

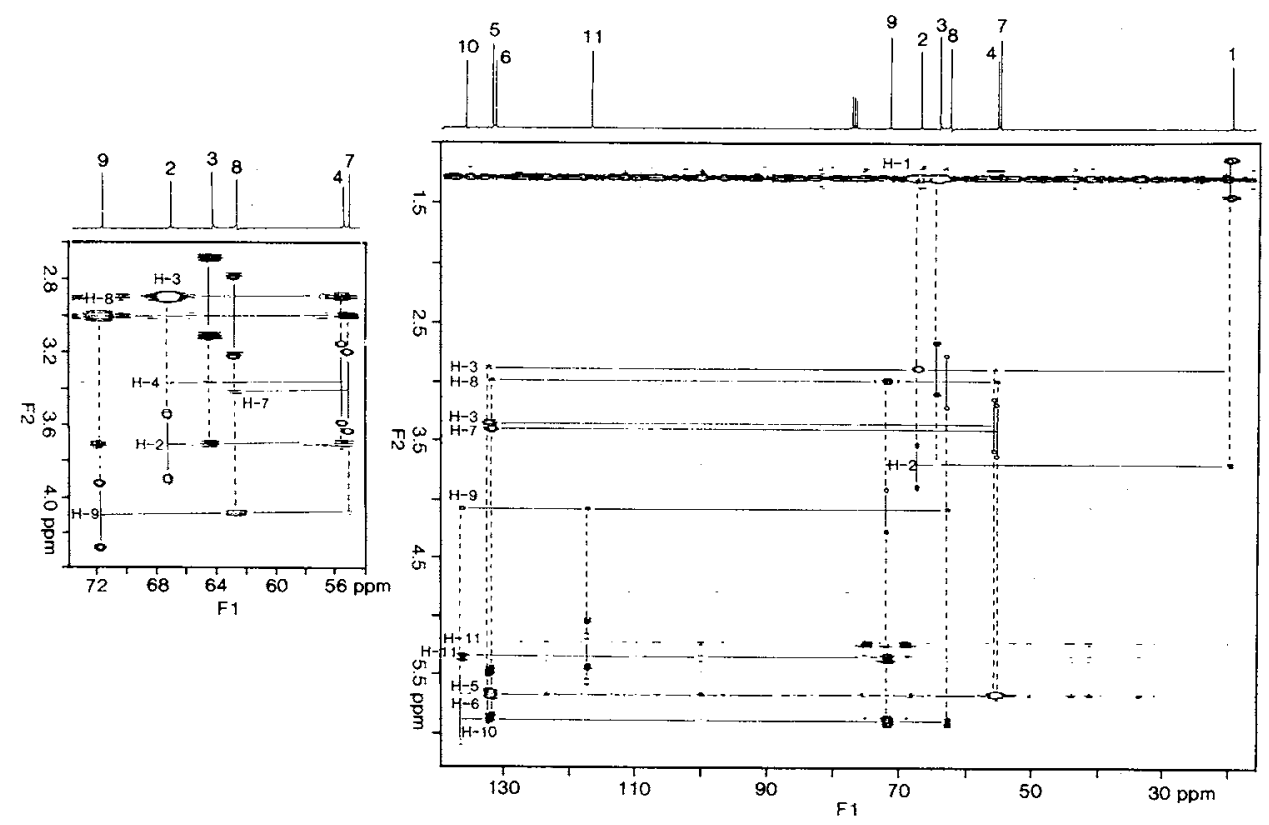


Table 2. ${ }^{1} \mathrm{H}$ and ${ }^{13} \mathrm{C}$ NMR spectral data ${ }^{a}$ for depudecin.

\begin{tabular}{|c|c|c|c|c|c|}
\hline $\mathrm{C} / \mathrm{H}$ & $\delta^{13} \mathrm{C}$ & $\delta{ }^{1} \mathrm{H}$ & & $\begin{array}{l}\mathrm{H} \text { multiplicity } \\
{ }^{2} J_{\mathrm{HH}},{ }^{3} J_{\mathrm{HH}},{ }^{4} J_{\mathrm{HH}}\end{array}$ & $\begin{array}{c}\text { Long range } \\
\text { connectivity in } \\
\text { HMQC and } \mathrm{HMBC}^{b}\end{array}$ \\
\hline 1 & $20.05 \mathrm{q}$ & 1.29 & $\mathrm{~d}$ & ${ }^{3} J_{\mathrm{HH}}=6.54$ & $1,2,3$ \\
\hline 2 & $67.34 \mathrm{~d}$ & 3.72 & $(\mathrm{dq})_{\mathrm{br}}$ & ${ }^{3} J_{\mathrm{HH}}=4.7,6.54$ & $2,1,3,4$ \\
\hline 3 & $64.50 \mathrm{~d}$ & 2.90 & $\mathrm{dd}$ & ${ }^{3} J_{\mathrm{HH}}=2.2,4.7$ & $3,2,4,5,1$ \\
\hline 4 & $55.67 \mathrm{~d}$ & 3.37 & $\mathrm{~m}(2 \mathrm{nd}$ order $)$ & ${ }^{3} J_{\mathrm{HH}}=2.2,(\sim 6)^{\mathrm{c}},{ }^{4} J_{\mathrm{HH}}(\sim 1)$ & $4,3,5,6,2$ \\
\hline 5 & $132.55 \mathrm{~d}$ & 5.69 & $\mathrm{~m}(2 \mathrm{nd}$ order $)$ & ${ }^{3} J_{\mathrm{HH}}=(\sim 6),(\sim 17),{ }^{4} J_{\mathrm{HH}}(\sim 1)$ & $5,4,6,7$ \\
\hline 6 & $132.06 \mathrm{~d}$ & 5.70 & m (2nd order) & ${ }^{3} J_{\mathrm{HH}}=(\sim 6),(\sim 17),{ }^{4} J_{\mathrm{HH}}(\sim 1)$ & $6,7,5,4$ \\
\hline 7 & $55.27 \mathrm{~d}$ & 3.42 & $\mathrm{~m}(2 \mathrm{nd}$ order $)$ & ${ }^{3} J_{\mathrm{HH}}=2.2,(\sim 6),{ }^{4} J_{\mathrm{HH}}(\sim 1)$ & $7,6,8,5$ \\
\hline 8 & $67.85 \mathrm{~d}$ & 3.00 & $\mathrm{dd}$ & ${ }^{3} J_{\mathrm{HH}}=2.2,4.5$ & $8,7,9,6$ \\
\hline 9 & $71.96 \mathrm{~d}$ & 4.10 & $(\mathrm{dddd})_{\mathrm{br}}$ & ${ }^{3} J_{\mathrm{HH}}=4.5,5.5,{ }^{4} J_{\mathrm{HH}}=1.1,1.4$ & $9,8,10,11$ \\
\hline 10 & $136.55 \mathrm{~d}$ & 5.92 & ddd & ${ }^{3} J_{\mathrm{HH}}=5.5,10.5,17.1$ & $10,9,8$ \\
\hline \multirow[t]{2}{*}{11} & $117.50 \mathrm{~d}$ & 5.29 & ddd & ${ }^{2} J_{\mathrm{HH}}=1.4,{ }^{3} J_{\mathrm{HH}}=10.5,{ }^{4} J_{\mathrm{HH}}=1.4$ & $11,10,9$ \\
\hline & & 5.38 & ddd & ${ }^{2} J_{\mathrm{HH}}=1.4,{ }^{3} J_{\mathrm{HH}}=17.1,{ }^{4} J_{\mathrm{HH}}=1.1$ & $11,10,9$ \\
\hline
\end{tabular}

a $400 \mathrm{MHz}$ for ${ }^{1} \mathrm{H}$ and $100 \mathrm{MHz}$ for ${ }^{13} \mathrm{C}\left(\delta\right.$ in $\left.\mathrm{CDCl}_{3}\right)$.

b Carbons showing ${ }^{\mathrm{n}} J$ coupling (where $\mathrm{n}>=1$ ) to protons in column 3 .

c Coupling constants given in parenthesis are those estimated by spin simulation (VNMR ver. 3.2).

constant between $3-\mathrm{H}(\delta 2.90, J=2.2 \mathrm{~Hz})$ and 4- $(\delta 3.37, J=2.2 \mathrm{~Hz})$, and that between $7-\mathrm{H}(\delta 3.42$, $J=2.2 \mathrm{~Hz})$ and $8-\mathrm{H}(\delta 3.00 J=2.2 \mathrm{~Hz})$, respectively. The stereochemistry of the C-5 $-\mathrm{C}-6$ double bond was assigned the $E$-configuration based on the coupling constant $\left(J_{5,6}=17.0 \mathrm{~Hz}\right)$ estimated by spin simulation (with VNMR ver. 3.2). The ${ }^{1} \mathrm{H}$ and ${ }^{13} \mathrm{C}$ NMR data were summarized in Table 2.

On the basis of the above results, the planar structure of depudecin was determined to be 2,9-dihydroxy-3,4;7,8-diepoxy-undeca-5,10-diene. In order to confirm the proposed structure and to determine the absolute stereochemistry, a single crystal X-ray analysis of the bis- $(1 S)-(-)$-camphanate (1b) of depudecin was performed. Crystal data: $\mathrm{C}_{31} \mathrm{H}_{40} \mathrm{O}_{10}$; monoclinic; space group $C 2 ; a=12.95(1)$, $b=19.52(2), c=13.54(1) \AA, \beta=115.39(6)^{\circ} ; V=3092(3) \AA^{3} ; Z=4 ; D x=1.230 \mathrm{~g} \mathrm{~cm}^{-3}$. The structure was solved by the direct method (MULTAN87) ${ }^{4}$. Two independent molecules (A and B) are found in the unit cell with each of the centers of the bond $\mathrm{C} 5$-C6 situated on a crystallographic 2-fold rotation axis although the molecule does not have a 2-fold symmetry. Therefore, the crystal structure consists of statistically disordered molecules such that the molecules appear to have $\mathrm{Cl}$ methyl and vinyl groups interchanged and superimposed. Moreover, the vinyl groups are disordered with two conformations in both molecules A and $\mathrm{B}$.

Positional parameters and anisotropic thermal parameters of non- $\mathrm{H}$ atoms were refined by block-diagonal least squares. In the least squares hydrogen atoms of the hydrocarbons were calculated and fixed at their ideal positions. The weighing scheme used was $w=1 /\left[\sigma^{2}\left(F_{0}\right)+0.00164\left|F_{\mathrm{O}}\right|^{2}\right]$ for $w^{1 / 2}|\Delta F| \geq 3, w=0$ otherwise. The final $R$ value $\left(\Sigma|\Delta F| \Sigma\left|\Delta F_{\mathrm{O}}\right|\right)$ was 0.058 for 1,807 observed reflections $\left(F_{\mathrm{O}}>3 \sigma\right)$ and $w R$ was $0.049, S=1.2363$. The atomic parameters, bond length, and angles have been sent to the Cambridge Crystallographic Data Center.

A computor-generated perspective view ${ }^{5)}$ of the bis-(1S)-(-)-camphanate (1b) is given in Fig. 4a and the crystal structure is shown in Fig. $4 \mathrm{~b}$. Based on the above results, the structure of depudecin was determined to be $(2 R, 3 S, 4 S, 5 E, 7 S, 8 S, 9 R)$-2,9-dihydroxy-3,4;7,8-diepoxy-undeca-5,10-diene (1a) as shown in Fig. 1. The absolute configuration was based on the configuration in the (1S)-(-)-camphanyl group which was already known. 
Fig. 4a. Perspective view of the molecule A.

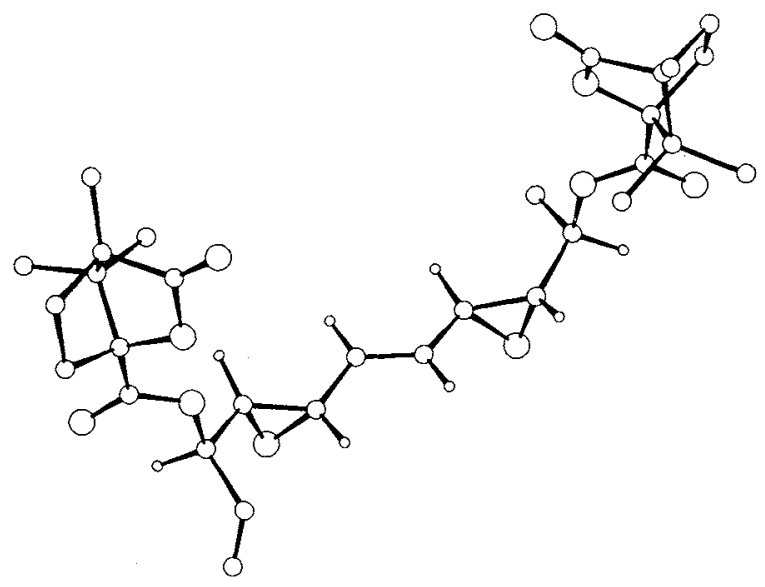

Fig. 4b. Molecular packing viewed from a direction along the $\mathrm{c}$ axis.

The molecule at the upper right is a molecule A, and the lower left one is a molecule $B$. The molecules $\mathrm{A}$ and $\mathrm{B}$ are about $\mathrm{b} / 2$ apart from each other.

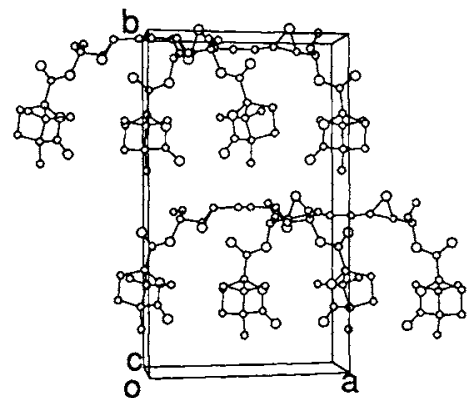

Fig. 5. Conversion of ras/src transformed NIH3T3 cells to apparently normal cells by treatment with depudecin.

ras/src NIH3T3 cells were cultured overnight in a $5 \% \mathrm{CO}_{2}$ incubator and the cells were incubated for further 24 hours in the absence (A) or the presence (B) of depudecin at a concentration of $1 \mu \mathrm{g} / \mathrm{ml}$.

(A)

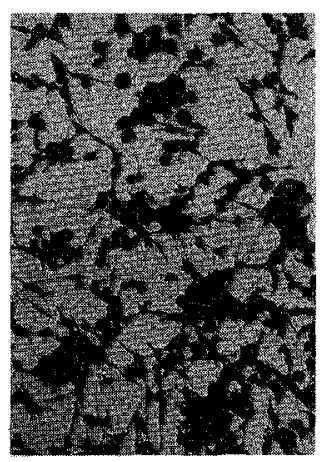

(B)

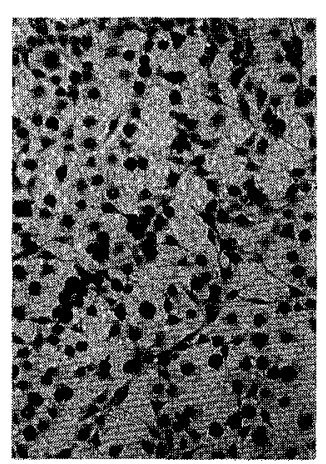

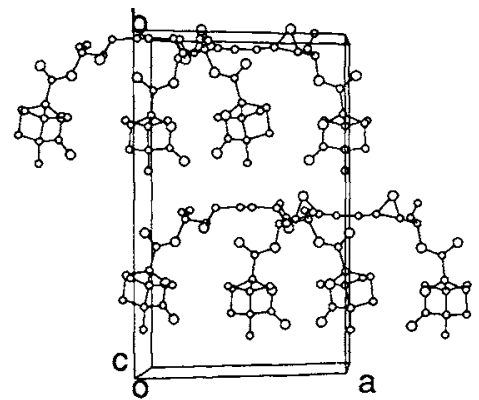

Fig. 6. Growth inhibition of ras/src NIH3T3 cells by depudecin.

Viable cells were measured by MTT assay.

T: Transformed phenotype, F: flat phenotype, --- mean.

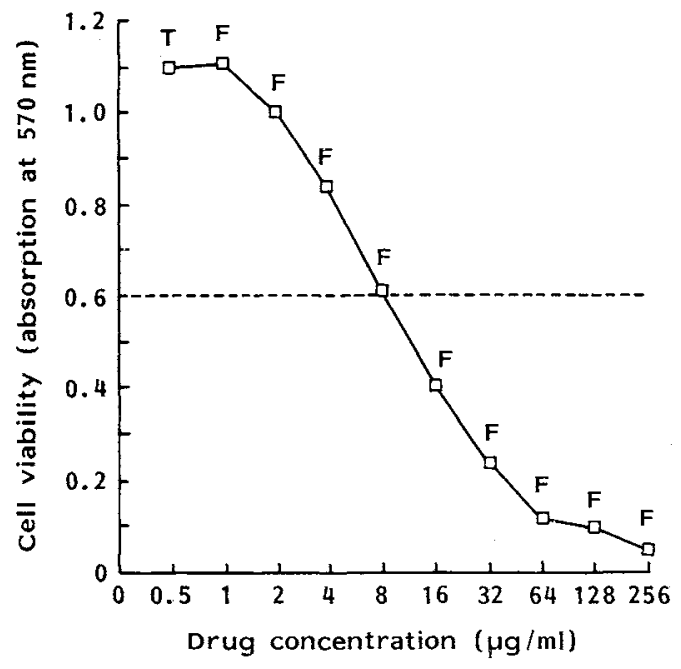




\section{Biological Activities}

Conversion of $\mathrm{ras} / \mathrm{src}$ transformed NIH3T3 cells to apparently normal cells by treatment with depudecin was observed as shown in Fig. 5. Relative low concentration $(1 \mu \mathrm{g} / \mathrm{ml})$ of depudecin was sufficient to induce the flat morphology, compared to the concentration $(8 \sim 10 \mu \mathrm{g} / \mathrm{ml})$ which showed the $50 \%$ inhibition of the growth of the same cells (Fig. 6).

The inducing activity of depudecin with the flat morphology was seen within 6 hours after the drug administration, which did not require new protein syntheses (data not sown). This morphological change was paralleled with the appearance of actin stress fiber inside of the transformed cells (data not shown), which was seen in the normal NIH3T3 cell. This activity of depudecin was reversible, since the flat phenotype of ras/src NIH3T3 cells was changed to the transformed one after further 24 hours incubation following removed of the drug. Detailed biological profiles of depudecin will be published elsewhere ${ }^{6}$.

Depudecin did not show any antimicrobial activity at a concentration of $1,000 \mu \mathrm{g} / \mathrm{ml}$ against strains of bacteria or fungi tested, including Staphylococcus aureus JC-1, Escherishia coli NIHJ-JC2, Enterococcus faecalis IFO 3181, Clostridium difficile ATCC 17857, Aspergillus niger IFO 6428, and Candida albicans M-9.

\section{References}

1) Itazaki, H.; K. Nagashima, K. Sugita, H. Yoshida, Y. Kawamura, Y. Yasuda, K. Matsumoto, K. Ishil, N. Uotani, H. Nakai, A. Terui, S. Yoshimatsu, Y. Ikenishi \& Y. Nakagawa: Isolation and structural elucidation of new cyclotetrapeptides, trapoxins $\mathrm{A}$ and $\mathrm{B}$, having detransformation activities as antitumor agents. J. Antibiotics 43: $1524 \sim 1532,1990$

2) Mosmann, T.: Rapid colorimetric assay for cellular growth and survival; Application to proliferation and cytotoxicity assays. J. Immunol. Methods 65: 55 63, 1983

3) Wiltshire, S. P.: Species of alternaria on brassicae. Mycological Papers 20:8 14, 1947

4) Debaerdemaker, T.; G. Germain, P. Main, C. Tate \& M. M. Woolfson: A System of Computor Programs for the Automatic Solution of Crystal Structures from X-ray Diffraction Data. University of York, England, and Louvain, Belgium, 1987

5) Mother well, W. D. S. \& W. ClegG: PLUTO. Program for Plotting Molecular and Crystal Structures. University of Cambridge (England), 1978

6) Sugita, H.; H. Yoshida, M. Matsumoto \& S. Matsutani: A novel compound, depudecin, induces production of transformation to the flat phenotype of NIH3T3 cells transformed by ras-oncogene. Biochem. Biophys. Res. Commun. 182: $379 \sim 387,1992$ 